\title{
Labour relations, collective bargaining and employee voice in SMEs in central and eastern Europe
}

\author{
Miklós Illessy*, Vassil Kirov**, Csaba Makó*** and Svetla Stoeva*****
}

\section{Summary}

Drawing upon the examples of Bulgaria and Hungary, this article explores employee representation and voice in SMEs in central and eastern Europe in the context of the spectacular development of the SME sector during the post-1990 transition and associated changes in labour relations and collective bargaining practices. The article examines the relationship between the regulation of employment relations and employee representation and voice. It suggests that the absence of formal channels of representation in SMEs hides the existence of a number of informal compromises between employers and employees over matters such as wages, working time, and health and safety conditions. The authors argue that future trade union strategies should be based on a clear understanding of these social realities.

\section{Sommaire}

Cet article examine, en se référant aux exemples de la Bulgarie et de la Hongrie, la voix et la représentation des travailleurs dans les PME en Europe Centrale et de l'Est dans le contexte de l'évolution spectaculaire du secteur des PME pendant la transition post-1990 ainsi que les changements qui y sont associés dans les relations de travail et les pratiques en matière de négociation collective. L'article analyse les liens entre la réglementation en matière de relations d'emploi et la représentation et la voix des travailleurs. Il suggère que l'absence de canaux formels de représentation dans les PME cache l'existence d'un certain nombre d'engagements informels entre les employeurs et les travailleurs sur des sujets tels que les salaires, le temps de travail, et les conditions d'hygiène et de sécurité. Pour les auteurs, les futures stratégies syndicales devraient être basées sur une compréhension claire des réalités sociales.

\footnotetext{
* Research Associate, Institute of Sociology, Hungarian Academy of Sciences, Budapest

** Research Fellow, Institute of Sociology, Bulgarian Academy of Sciences, Sofia

*** Professor, Institute of Sociology, Hungarian Academy of Sciences, Budapest

**** Assistant Professor, Department of Sociology, Sofia University, 'St.Kliment Ohridski'
} 


\section{Zusammenfassung}

Am Beispiel Bulgariens und Ungarns werden in diesem Artikel die Vertretung und die 'voice' von Arbeitnehmern in KMU in Mittel- und Osteuropa untersucht, vor dem Hintergrund der spektakulären Entwicklung des KMU-Sektors seit Beginn des Umbaus nach 1990 und den damit verbundenen Änderungen der Arbeitsbeziehungen und der Tarifverhandlungspraxis. Der Artikel prüft die Zusammenhänge zwischen der Regulierung der Beschäftigungsbeziehungen, der Arbeitnehmervertretung und der Mitsprache. Er formuliert die These, dass der Mangel an offiziellen Kanälen für die Vertretung in KMU die Existenz einer Reihe von informellen Vereinbarungen zwischen Arbeitgebern und Arbeitnehmern kaschiert, so zum Beispiel über das Entgelt, die Arbeitszeit und Gesundheits- und Sicherheitsfragen. Die Autoren plädieren dafür, bei künftigen Gewerkschaftsstrategien diese soziale Realität deutlicher zur Kenntnis zu nehmen.

$$
\nLeftarrow *
$$

Keywords: central and eastern Europe, transformation, SMEs, labour relations, trade unions

\section{Introduction}

Before 1990 employment in central and eastern European countries (CEECs) was concentrated in large state-owned companies and jobs were secure. During the transition of the past 16 years, employment has gradually transferred to the emerging small and medium-sized enterprise (SME) sector and has become precarious. Employment in SMEs in CEECs is generally outside the coverage of collective bargaining, which remains concentrated on large enterprises and the public sector. Taking account of this transitional context and drawing upon the examples of Bulgaria and Hungary, we argue that SMEs play a dual role in the economic performance of CEECs in promoting economic and social development while simultaneously generating informal mechanisms that substitute for formal labour relations. Large-scale European quantitative surveys provide information about the presence or absence of trade unions or the existence of such participative institutions as works councils in SMEs. ${ }^{1}$ Such surveys, however, cannot explain the realities of social relations in the sector in the post-socialist societies or allow us to draw conclusions about the nature of employee voice. On the basis of the 12 case studies of Bulgarian and Hungarian SMEs carried out as part of the SMALL project, this paper examines the relationship between the regulation of employment relations in SMEs and employee representation and voice. This examination is conducted in the context of (1) the spectacular development of the SME sector during the post-socialist transition; (2) changing labour relations, and (3) collective bargaining

1 Carried out by organisations such as the European Industrial Relations Observatory (EIRO), International Labour Office (ILO), OECD or the Observatory of European SMEs. 
practices. The paper then (4) provides examples of employee representation in several sectors of the economy and (5) makes a number of recommendations to policy-makers and the trade unions in the region.

\section{The rise of the SME sector in the post-socialist economies}

In the context of the socio-economic transformation, the development of the SME sector in CEECs is regarded as an important condition for economic growth and the creation of employment. Throughout the region SMEs grew continuously throughout the 1990s, both in absolute numbers and in their importance for employment, production, value added and exports (Eurostat 2003). Their development took place in an environment of institutional support and public policies that were not concerned with the type of employment generated in small businesses. The fundamental liberalisation of economic life, the de-monopolisation of enterprises and the emergence of autonomous social and economic actors in the post-socialist period influenced organisational structures. All these processes were accompanied by the establishment of a new system of industrial relations, which is examined in the second part of this article. Economic restructuring and fast growing unemployment forced large groups of the population to look to the emerging SME sector for their economic survival. ${ }^{2}$

In the social sciences, the early 1990s saw a number of studies of the so-called 'transformation economies', which enriched the literature on the political, economic and social changes that were taking place in CEECs. During this decade, the theoretical concept of 'path-dependency' helped social scientists refute the view of change as occurring within an 'institutional vacuum', a view which overlooked the importance of the varied socioeconomic and cultural histories of these countries. As Chavance (1995: 288) has stated; 'the path-dependent emergence of a new, post-socialist form of capitalism calls for a complex evolutionary interpretation of this great transformation, as opposed to the "big bang" view which, as the metaphor itself suggests, overlooks the historical legacy'. The 'path-dependency' approach provides a better understanding of the variety of development trajectories in the post-socialist economies in the CEE region and highlights the evolutionary character of social-economic and technological development. The explanatory strength of this approach was helpful in understanding the 'destruction' of the statesocialist political and economic regime, together with the 'reconstruction' of the market economy and the democratic political institutions in the post-socialist economies. This view enables us to understand the uneven development of the post-socialist firms and their management. Thus privatisation, market competition and foreign direct investment (FDI) were the main drivers of economic development and modernisation in the CEECs, but 'social filters' (the labour relations system, educational and training institutions and regional development agencies) also played a significant role, as it was

2 The SME sector was not a completely new phenomenon, deriving from the post-socialist transition. Some proto-entrepreneurial initiatives existed during the $1980 \mathrm{~s}$, as a result of various attempts to overcome the shortcomings of the state socialist planning system. However, following the 'start' of the transformation process, the creation of private firms became a key tool by which citizens adapted to the emerging market economies. 
Table 1: Changing 'organisational morphology' in the post-socialist economies:

\begin{tabular}{|c|c|c|c|c|c|c|}
\hline & EU-15 & $\mathrm{ACC}(1)$ & $\mathrm{CZ}$ & EE & $\mathbf{C Y}$ & LV \\
\hline \multicolumn{7}{|c|}{ Industry and services (3) } \\
\hline $\begin{array}{l}\text { All sizes (units) } \\
\text { of which: }\end{array}$ & 13447079 & 2476463 & 741762 & 2946 & : & 36032 \\
\hline Micro (\%) & 90.6 & 93.4 & 94.6 & 78.5 & : & 76.9 \\
\hline Small (\%) & 7.9 & 5.2 & 4.4 & 17.8 & : & 18.9 \\
\hline Medium (\%) & 1.2 & 1.2 & 0.9 & 3.3 & $:$ & 3.7 \\
\hline Large $(\%)$ & 0.2 & 0.3 & 0.2 & 0.5 & : & 0.5 \\
\hline \multicolumn{7}{|c|}{ Industry and construction } \\
\hline $\begin{array}{l}\text { All sizes (units) } \\
\text { of which: }\end{array}$ & 3656464 & 729755 & 252297 & 6775 & 1214 & 7603 \\
\hline Micro (\%) & 84.0 & 88.7 & 91.8 & 59.2 & : & 57.8 \\
\hline Small (\%) & 13.2 & 8.0 & 6.1 & 31.0 & : & 31.3 \\
\hline Medium (\%) & 2.3 & 2.7 & 1.7 & 8.4 & : & 9.2 \\
\hline Large $(\%)$ & 0.5 & 0.6 & 0.4 & 1.3 & $:$ & 1.7 \\
\hline \multicolumn{7}{|l|}{ Services } \\
\hline $\begin{array}{l}\text { All sizes (units) } \\
\text { of which: }\end{array}$ & $9790 \quad 615$ & 1746708 & 489465 & 22690 & : & 28429 \\
\hline Micro (\%) & 93.1 & 96.3 & 96.0 & 84.2 & : & 82.0 \\
\hline Small (\%) & 6.0 & 4.0 & 3.5 & 13.8 & : & 15.6 \\
\hline Medium (\%) & 0.8 & 0.6 & 0.4 & 1.8 & : & 2.2 \\
\hline Large (\%) & 0.1 & 0.1 & 0.1 & 0.2 & : & 0.2 \\
\hline
\end{tabular}

(1) Acceding and candidate countries.

(2) Micro enterprises, 5-9 employees and not 1-9 employees; total for all enterprises covers 5 and more employees.

(3) PL, breakdown by enterprise size class, 2000. Source: Eurostat, Structural business statistics (theme 4r'sts'size clas). Source: Eurostat 2003, p. 34.

through these that the various social actors (owners, managers, the state, workers and their representative associations) experienced and 'digested' the changes.

However, none of the above-mentioned approaches would appear sufficient on their own to explain the factors triggering the spectacular growth of the SME sector in the post-socialist societies in terms of employment. The non-enforcement of legislation covering employment and employment representation must also be taken into account.

In Bulgaria, a review of the available data illustrates the spectacular growth of SMEs for the period 1989-2004. If at the beginning of the transition in 1989 the SME sector was almost non-existent (there were some 24500 registered private companies), almost 13 years later SMEs represented 99\% of all enterprises (or an estimated 216000 in 2004). By 2004 SMEs generated $79 \%$ of employment, $75 \%$ of turnover and $61 \%$ of the value added to private enterprises. ${ }^{3}$ 
spectacular growth of SMEs

Number of enterprises, 2001

\begin{tabular}{|c|c|c|c|c|c|c|c|l|}
\hline LT & HU (2) & MT & PL & SI & SK & BG & RO & TR \\
\hline 57621 & 56125 & $:$ & 1417142 & 71472 & 36910 & $:$ & 300310 & $:$ \\
\hline 81.5 & 51.0 & $:$ & 96.5 & 91.0 & $:$ & $:$ & $:$ & $:$ \\
\hline 14.9 & 40.2 & $:$ & 2.4 & $:$ & 23.4 & $:$ & 9.9 & $:$ \\
\hline 3.2 & $:$ & $:$ & 0.9 & $:$ & 5.2 & $:$ & 2.6 & $:$ \\
\hline 0.4 & $:$ & $:$ & 0.2 & $:$ & $:$ & $:$ & $:$ & $:$ \\
\hline & & & & & & & & \\
\hline 12993 & 23329 & $:$ & 378048 & 26302 & 10259 & $:$ & 57753 & $:$ \\
\hline 64.6 & 41.7 & $:$ & 92.5 & 87.3 & 50.1 & $:$ & 67.0 & $:$ \\
\hline 25.4 & 44.6 & $:$ & 4.8 & $:$ & 34.2 & $:$ & 21.2 & $:$ \\
\hline 8.6 & $:$ & $:$ & $:$ & $:$ & 11.9 & $:$ & 9.0 & $:$ \\
\hline 1.5 & $:$ & $:$ & $:$ & $:$ & 3.7 & $:$ & 2.8 & $:$ \\
\hline & & & & & & & & \\
\hline 44628 & 32796 & $:$ & 1089094 & 45170 & 26651 & $:$ & 242567 & $:$ \\
\hline 86.4 & 57.6 & $:$ & $:$ & 93.2 & $:$ & $:$ & $:$ & $:$ \\
\hline 11.9 & 37.0 & $:$ & $:$ & 5.9 & 19.2 & $:$ & 7.2 & $:$ \\
\hline 1.6 & 4.6 & $:$ & 0.5 & $:$ & 2.6 & $:$ & 1.1 & $:$ \\
\hline 0.2 & 0.8 & $:$ & 0.1 & $:$ & $:$ & $:$ & $:$ & $:$ \\
\hline
\end{tabular}

In Hungary, the fundamental changes in ownership within the economy, from the end of the 1980s, also significantly influenced the organisational morphology of the country. As a result, the number of registered businesses doubled between 1990 and 1995 and reached 1 million by 1995 . The number of registered enterprises, approximately 400000 in 1990, grew by more than two and a half in a decade. The overwhelming majority $(95 \%)$ were based upon self-employment, and these doubled in number by the mid1990 s, but then fell back somewhat due to recession and unfavourable regulations. Today, $75.5 \%$ of the 1.1 million registered companies are actually in operation.

\section{SME characteristics}

Comparing the growth of the SME sectors in CEECs, using the examples of Bulgaria and Hungary, we can draw some general conclusions. After 1989 employment patterns changed significantly. The share of employment in SMEs started from almost zero in Bulgaria. In both countries this share has grown continuously over the last 15 years.

3 ASME, Annual Report 2004, http://www.sme.government.bg/en/AnnualReportSME2004EN.pdf 
However, it seems that the role of SMEs in employment generation and in economic performance was realised later in Bulgaria than in Hungary. In the former, SMEs for a long time could only partially absorb the outflows from the labour market, as a result of the liquidation of large enterprises and economic restructuring (Beleva 2001). Yet, regional and sectoral differences are important in both countries. For example, examining the sectoral distribution of firms by size, in Bulgaria the largest number of firms can be found in the following sectors: real estate, rental and business services (227 946 firms) and trade, repair of motor vehicles and consumer goods (195 472 firms). In Bulgaria more than half of SMEs operate in the sphere of commerce, $12 \%$ are in manufacturing, about $10 \%$ in real estate and business services and another $10 \%$ in hotels, restaurants and catering. 'In Hungary, the distribution of enterprises by sectors is more balanced: $28 \%$ of the enterprises operate in the real estate sector, $24 \%$ in commerce, $10-10 \%$ in manufacturing and in construction, $6 \%$ belong to the category of transport and communication, $5 \%$ operate in the field of hotels and restaurants, while the sectors of financial intermediation, education and health care are represented by $3-3.3 \% .8 \%$ of the SMEs belong to the category of other businesses.' (Központi Statisztikai Hivatal (Hungarian Central Statistical Office) $(2006)^{4}$

SMEs developed the ability to generate informal mechanisms for coping with the turbulent institutional environment of the post-socialist economies. They relied extensively on flexible practices - such as keeping two sets of books and a combination of formal and informal ${ }^{5}$ employment contracts - and this had a major impact on the labour market and employment relations in both the Bulgarian and Hungarian economies. In addition, it is worth noting the significant differences in the innovation rate by size in the CEECs. As the size of the firm increases the innovation activity within the firm becomes more intensive. A similar pattern of innovation activity can be observed in the EU-15 countries (see Palmieri, in this issue); however, in the latter the size of the firm where the impact can be observed is smaller.

\section{Labour relations and collective bargaining in the CEE region - examples from Bulgaria and Hungary}

The present labour relations system in CEECs was established in the early 1990s, after the collapse of the state socialist political and economic regimes. This system was built on the basis of institutional transfers, influenced by international organisations such as the International Labour Organisation. The state, the emancipated unions (reformed old unions such as CITUB in Bulgaria or MSZOSZ in Hungary or newly established confederations such as Podkrepa in Bulgaria or Liga in Hungary) and newly established employers' organisations (in Bulgaria formed mainly by company managers appointed by the state, belonging to the Bulgarian Industrial Association) entered into social

4 This classification is similar to the NACE classification accepted by all national statistical offices in Europe. Data refer to 2004, source: KSH (2006), pp 26-28.

5 In this article we do not enter into the debate over which is the more appropriate term - formal/informal or official/unofficial and we use the terms interchangeably. 
dialogue over the direction of reform and contributed to the establishment of a number of tripartite institutions.

\section{Trade unions}

Whereas at the beginning of the transformation process trade union density rates in the former socialist countries were extremely high, due to compulsory membership, from 1990 onwards union membership in all CEECs experienced a dramatic decline. Table 2

\section{Table 2: Trade union density rates and membership composition, $1995-2002^{6}$}

\begin{tabular}{|l|c|c|c|c|c|}
\hline & \multicolumn{3}{|c|}{ Union density rates } & \multicolumn{2}{c|}{ Share of all members } \\
\hline & $\mathbf{1 9 9 0}$ & $\mathbf{1 9 9 5}$ & $\mathbf{2 0 0 2}$ & Female & Public \\
\hline Belgium & 53.9 & 55.7 & $55.8^{*}$ & n.d. & n.d. \\
\hline France & 10.1 & 9.8 & $9.7^{*}$ & $48.3^{* *}$ & $66.3^{* *}$ \\
\hline Hungary & n.d. & 63.4 & 19.9 & $48.7^{* *}$ & $70.3^{* *}$ \\
\hline Italy & 38.8 & 38.1 & 34.0 & $38.3^{*}$ & $53.1^{*}$ \\
\hline Portugal & 31.7 & 25.4 & n.d. & n.d. & n.d. \\
\hline Sweden & 80.0 & 83.1 & 78.0 & 52.7 & 47.9 \\
\hline UK & 39.3 & 34.1 & 30.4 & 43.7 & 47.4 \\
\hline Czech Republic & 78.7 & 46.3 & 25.1 & $57.9^{*}$ & $44.5^{*}$ \\
\hline Poland & n.d. & 32.9 & $14.7^{*}$ & $55.1^{*}$ & $76.6^{*}$ \\
\hline Slovakia & 78.7 & 57.3 & 35.4 & $49.6^{*}$ & $70.9^{*}$ \\
\hline Slovenia & n.d. & n.d. & 41.0 & $49.4^{*}$ & $76.2^{*}$ \\
\hline Average EU-25*** & n.d. & 32.6 & $26.4^{*}$ & n.d. & n.d. \\
\hline Average EU-15*** & 32.8 & 31.0 & $27.3^{*}$ & n.d. & n.d. \\
\hline Average EU-10*** & n.d. & 42.7 & $20.4^{*}$ & n.d. & n.d. \\
\hline
\end{tabular}

Data available only from 2001.

** The data on membership composition (share of female members; share of members in the public sector) are calculated from sample surveys of the International Social Science Programme (ISSP) and relate to 1998.

*** Weighted averages. In the event of missing data, the nearest year is taken into account.

6 The data on union density for Bulgaria were not available from official sources, but other sources (e.g. Kirov 2005) provide the following estimates: about $42 \%$ in 1995 and about $26 \%$ in 2003. Density rates for EU-15 countries are standardised, i.e. without unemployed and self-employed, retired employees and student members, following the model in Ebbinghaus and Visser (2000). In the case of the UK, figures are calculated from the Labour Force Survey. Elsewhere they are recalculated from administrative sources. See also OECD 2004. The EU-10 figures are non-standardised and follow nationally based statistics collected by the Institut des Sciences du Travail of the Université Catholique de Louvain, Monographs on the Situation of social partners in the candidate countries, Brussels, December 2003, a research project conducted on behalf of the Employment and Social Affairs DG of the European Commission. Quoted by European Commission 2004, p. 19. Table 2 is an edited version of the original one containing data only for countries involved in the SMALL project. 
shows, however, that, within the CEECs, there are substantial differences between countries often considered as homogenous. In 2002 the highest unionisation rate was registered in Slovenia (41.0\%) and the lowest rate was found in Poland (14.7\%) in spite of the legacy of a strong and militant trade union movement symbolised by the Solidarity trade union.

In addition, union density rates vary substantially between private and public sectors. For example in Hungary, Poland and Slovakia more than every second union member works in the public sector. The higher density rates in the public sector are explained partly by the institutional heritage of the post-socialist countries which became EU members (on 1 May 2004) and by the difficulties trade unions have in recruiting members in the private sector, especially in SMEs and newly established firms (i.e. firms created in the form of 'greenfield' investments in the so-called 'trade union free zones') (Makó and Novoszáth 1995).

Trade union representation is more fragmented in Hungary, where seven trade union confederations were created after the collapse of the state socialist system, than in Bulgaria where two confederations have cooperated well since 1995. In Hungary labour relations have a dual character; as well as the historical representation of workers' interests by trade unions, works councils facilitate employee participation in the companies' decision-making system. However, these two channels of labour relations are interrelated: the existence of works councils is closely connected with the presence of trade unions. According to data from a statistically representative survey carried out in 2002 in Hungary, works councils, trade unions and collective agreements all increase with the size of the firm (Neumann 2002). In 2006 Bulgaria adopted the European Directive 2002/14/EC on Information and Consultation into its labour code.

\section{Employers' organisations}

Employers' organisations are similarly fragmented in both countries. In Hungary there are nine employers' organisations at national level, four of which represent the interests of SMEs. In Bulgaria four of six nationally representative organisations of employers represent the interests of SMEs (either exclusively or as part of their representing a range of enterprises). Employers' organisations cover a minority of the businesses in the country (according to national statistics, in 2003, $15 \%$ of companies were members of employers' associations). They are relatively weak in terms of human and financial resources as well as services provided to their members.

\section{Labour legislation}

Both Hungary and Bulgaria implemented new labour codes (Hungary in 1992 and Bulgaria in 1993) providing a legislative framework for labour relations. However, the logic of the new labour codes reflects the employment practices of the large firms, which dominated the former state socialist political and economic regimes. These labour codes do not reflect the multiplicity of employment relations within the SME sector: in particular, the coexistence of formal and informal regulation and the dominance of individual bargaining. 


\section{Collective bargaining}

In the CEECs under examination, as elsewhere in Europe, there is a clear relationship between the size of the firms and collective bargaining coverage. Table 3 shows the only statistical data available on the relationship between the size of the firm and collective agreement coverage in Hungary (there are no corresponding data for Bulgaria), which illustrate the weak role of collective bargaining within the SME sector.

\section{Table 3: Collective bargaining by company size in Hungary (1998)}

\begin{tabular}{|l|c|}
\hline Size categories of firms (number of employees) & Share of companies with collective agreements \\
\hline $5-20$ persons* & $0.1 \%$ \\
\hline $20-49$ persons & $1.1 \%$ \\
\hline $50-299$ persons & $11.7 \%$ \\
\hline $300-499$ persons & $46.4 \%$ \\
\hline $500-999$ persons & $67.3 \%$ \\
\hline 1000 and more & $75.4 \%$ \\
\hline
\end{tabular}

* Data on collective bargaining are often not available for firms employing fewer than four persons. Source: Neumann 2002, p. 6.

\section{Employee voice and representation in the Bulgarian and Hungarian SMEs - case study evidence from the SMALL project}

Prior to the SMALL project there was little information on employment relations and employee voice in the emerging small businesses of the CEECs. The interest of researchers often lay with the emergence of the entrepreneurs themselves rather than the experience of employees. For many observers of the post-socialist countries during the early 1990s it was clear that the working conditions in the emerging SMEs were different from those in large enterprises, but this was interpreted as a 'temporary phenomenon', which would pass with the development of the market economy. Over the last decade it has became evident that the nature of employment in SMEs was a fixed and not a temporary phenomenon. Examination of violations of social and even human rights (KNSB 2000) in SMEs has taken place largely on the basis of media reports rather than more in-depth research within SMEs.

\section{Employment relations: the combination of formal and informal practices}

The case studies of SMEs in Bulgaria and Hungary include three based in the information and communications technology (ICT) sector (two from Bulgaria and one from Hungary); two in the clothing sector (one from each country); three from the hotel and catering sector (two from Bulgaria and one from Hungary); two Bulgarian case studies of very small retailers; one Hungarian study based in personal services and one study of 
a Bulgarian industrial subcontractor. Seven of the 12 cases were at or around the micro level (under ten employees); one was small (under 50) and four medium-sized (50-249). For Bulgaria, two of the case studies, one hotel and another ICT company, were directly foreign-owned (by Greek and Belgian interests) and there was a minority foreign owner in another ICT company.

On the basis of the case studies conducted by the SMALL project we argue that social relations in these SMEs cannot be characterised as unregulated or as dominated by the type of paternalist relations considered characteristic of family-run businesses. The fact that in the majority of these enterprises there was no union representation or workers' councils does not mean that employment relations reflect the operation of unfettered owners' and management prerogatives. Despite the lack of formal regulation in the firms that were studied, there were processes of adjustment and adaptation which will be discussed below.

The reality of social relations in SMEs in CEECs reflects a number of factors. Small and micro firms tend to be less 'visible' and less subject to regulation by the authorities, as a result of their 'passive voice' strategy of 'evasion' (Stoeva 2005). ${ }^{7}$ Informal employment relations and other non-institutional practices are typical examples of such a strategy. Often small firms have 'closed' recruitment practices based upon friendship and family. SMEs rarely cooperate in business associations ${ }^{8}$ and they may be reluctant to enter into relations with the state administration, which is supposed to encourage them. This behaviour is motivated by 'self-protection' and is associated with a lack of trust in the state and its institutions. Micro and small firms seem to draw back from the institutionalised formal market relations' mechanisms, including with regard to labour relations.

As has already been mentioned, this means that often there are important differences between legislation and practice. For example, in the case of a small Bulgarian retailer the manager stated his view that it was impossible fully to apply existing health and safety legislation in the field of small firms (in this case a small shop) - in his opinion the law should be applied only in large production enterprises. Within most of the case studies employees under contract coexisted with workers whose status was unclear (for example, probation was on the basis of verbal agreement or they had no formal contract).

In the case of both pay and working time, actual conditions in SMEs often did not correspond to the strict stipulations of legislation or the individual labour contract. Often employees were unfamiliar with the content of their labour contract, not because they did not have a copy of it, but more likely because working conditions were so different in practice: thus, non-compliance with regulations was not seen as important.

7 The strategy of 'evasion' (of legislation) is used by those economic actors who generally possess less economic freedom. The strategy is used to diminish high transaction costs such as access to information, taxation, capital, etc.

8 Examples from the Bulgarian small companies show that there is no interest for such membership. As one owner of an ICT company said: 'this kind of organisation imitates activity and in practice they are doing nothing'. 
In terms of workplace representation in Bulgaria, enterprises with 20 or more employees that under law are required to have committees on working conditions, had rarely established them. The widespread existence in the case studies of employment relations based on 'people you know', on loyalty or trust, and the consequent informal character of employment relations discourages compliance with legal requirements on both sides - by employers and employees. Social regulation based upon individual bargaining reflects the informal basis of employment relations, underpinned by personal loyalties, and coexists with employment relations based upon collective bargaining. ${ }^{9}$ Conflict resolution practices support the coexistence of both forms of regulation. For example, in the Bulgarian context violations of labour contract clauses were rarely resolved through institutional or representational channels, but rather through 'exit' or through the mobilisation of personal networks. The case studies suggest that this difference between prescription and practice is not only the result of unilateral decision-making by owners and managers. Often it is the result of mutually constructed compromises between the employer and the employees. These compromises are considered below.

\section{Wage regulation: the dominance of individual and informal bargaining}

The case studies demonstrate that in most instances wages are paid as 'cash in hand' in order to avoid social insurance payments and to increase disposable income for employees, especially when, at the level of the state, social security budgets are in deficit and unable to cope effectively with risk (health, pensions, unemployment). Paying a minimum working salary does not lead to the total avoidance of social insurance, but it helps to avoid high social insurance payments. It is common practice that, in order to reduce the social cost of employment and the amount of income taxes paid by employees, the employer and employee agree that remuneration be divided into two parts: the first is the minimum wage (with the obligation of social insurance and income tax payment), while the second part is not taxed but goes directly to the employees. The fact that part of the wage is paid cash in hand is not something generally imposed by the employer in the case of a Bulgarian food retail shop the management respondent reported that it was done in cooperation with the employee. There was thus a difference between the wages stated in labour contracts and the real remuneration received by employees. Even in medium-sized companies, such as the case study of a Bulgarian hotel, owned by an international chain, interviews showed that real salaries did not correspond to those in the labour contract as the employee respondent stated:

Only the minimal salary is written [in the contract] or a bit above the minimal. Generally, none of the employers pays insurance on the real amount of salary. They write smaller amounts (in order) to pay less insurance. Everywhere is like that.

In the Hungarian clothing industry, however, a wider problem was reported by a trade union leader: 'many people who contact us report delayed or unpaid salaries.'

9 As indicated in Table 3, although individual bargaining dominates there is also a segment of the SME sector which is regulated by collective bargaining. 
Wage-related collective bargaining and the negotiation of minimal social insurance thresholds between social partners can, therefore, only partially influence this individualised bargaining process, especially in sectors where the collective bargaining coverage is very low - such as retail, hotels and catering or ICT in the case of Bulgaria. Wage levels and structure (part paid officially and part paid unofficially) in general depend on the sector of activity and the size of the company, with informal practices tending to be more frequent in small companies. Wage formation mechanisms in Bulgaria appeared obscure in some of the case examined, for example in small shops, and mediated by the 'proximity' of employees to the owners and managers. Only in some medium-sized enterprises owned by foreign investors or managers (for example, in the hotels and catering, and the chemical sectors in Bulgaria) did we observe more transparent wage formation mechanisms and performance-related pay based upon individual or team working. Bonus systems, while existing, often also seemed to be obscure and dependent on employer prerogative, but also sometimes informed by friendship/family relations with the employees.

\section{Working time and working conditions}

The case studies suggest that SMEs only partially observe labour legislation on working time. All of the owners and managers interviewed showed some acquaintance with the legislation. However, typical for these firms, despite some sectoral differences, is the informal organisation of work, including the regulation of working time. External environmental factors, primarily the process of deregulation, define the relatively 'liberal' right of the employers to determine the working time of their business, for example, in retail.

Flexibility of working time is extremely important for both actors in 'negotiations'. 'Longer working hours are among the three most often violated labour standards in Bulgarian SMEs during the post-communist transition, together with "work without a labour contract" and the "minimum working salary to avoid high social insurance payments"' (European Foundation for the Improvement of Living and Working Conditions (2001:1). Similarly in Hungary it has been reported that employees sometimes worked such hours in exchange for extra pay but more often in the hope that it would facilitate career development or in return for flexibility in working hours (in ICT and retail).

The case studies show that, depending on the sector or business activity, the employer might ask employees to work longer hours, during the weekend or national holidays, or, in tourism, during high season. In smaller case study organisations these longer working hours were not paid. Employees sometimes worked such hours in 'exchange' for extra pay (in larger enterprises), but more often in the hope that it would facilitate career development or in return for flexibility in working hours (in ICT and retail). In the ICT company case studies in Bulgaria employees accepted that they would stay until late when it was necessary, in return they could take 'emergency' leave whenever they wanted to, as long as the manager was informed. The impact of such individual bargaining power based on personal relations in small firms could be interpreted as providing more 
freedom and flexibility both to the employer and employees. In exchange for longer working hours the owners and managers give the employee more flexibility over working time, enabling them to take time off for domestic emergencies or for personal business. However, from another perspective that informality might be seen as limiting the freedom of the employee to refuse extra work if asked to carry it out. In the case of a Bulgarian ICT company working time schedules were governed by external factors; employees could start work at any point in the period between 8.30 and 10.00 am and finish between 6.30 and $7.30 \mathrm{pm}$; each was free to allocate their own time as long as they fulfilled their working responsibilities (see also Alves et al., in this issue). The owner explained that each of the employees determined their working time in accordance with the needs of the clients:

When we have no work with the clients everyone is free to come and stay whenever he/she wants to.

However, at the same time:

We are serving a lot of clients, they are the ones who determine the working time of employees - at what time to be at their offices and how tasks should be undertaken. Thus working time depends on clients' requirements.

A further mismatch between labour legislation and employment practice in SMEs can be found in the length and regularity of rest periods, breaks and annual leave, which again are informally regulated.

The other domain for informal negotiation, at least in some SMEs, is health and safety. These 'negotiated' arrangements are built on the basis of mutually acceptable solutions, which could differ from what is prescribed by law. In general, compliance with labour legislation depends on the size of the company; the bigger the firm, the stricter the implementation of health and safety practices. The case studies demonstrated that in the micro and the small firms the level of health and safety observation is not rigorous. In those firms it appeared that neither employers nor employees were interested in health and safety. In Bulgaria, the recently introduced provision for the regular medical examination of employees is problematic, because the Labour Medicine Offices (LMOs) have no financial incentive to sign contracts with SMEs (due to the small number of employees). In small companies health and safety committees rarely exist. In mediumsized companies, committees on Health and Safety Conditions formally exist in many cases but generally are not active (in some cases not functioning at all). One exception, illustrated in both the Bulgarian and the Hungarian case studies, are the subcontracting companies working for foreign contractors, who are keener to develop health and safety policies and measures under pressure from their contractors. However, even in these cases the observation of legislation might exist in theory rather than practice (for example, the company might have a contract with an LMO, but it was unclear whether medical examinations of personnel were actually carried out). According to the owners and managers interviewed in one of the Bulgarian case studies, they lack information from the authorities about health and safety requirements. Most of the respondents (excluding a case study in a larger hotel) agreed that the government programmes and legal 
initiatives were unclear and difficult to understand and adopt by employers, because of the investment they required.

Vocational training is rarely an issue addressed by Bulgarian SMEs. Evidence from the National Statistics Institute (NSI) survey on continuous vocational training (CVT) in Bulgaria showed that few hours are spent on training, particularly in micro and small enterprises; few resources are allocated to training activities and very few enterprises have a written plan and specific budget for CVT. The lack of formal training was borne out by the case studies, with the exception of initial on-the-job training. In Bulgaria there was no accredited training in any of the case study organisations, except in a tourism company, which followed the standards of an international chain. In another case - a clothing company in Bulgaria, experienced workers were asked to train the newcomers. In a number of the case studies self-generated training was a strategy adopted by the employees, not only prior to joining the firm, but also whilst working there.

\section{Representation}

In the majority of firms studied in Hungary and Bulgaria it appeared that both owners and employers and employees preferred the 'informal regulation' of employment relations. In the ICT cases examined in Bulgaria a manager insisted on the fact that:

Highly qualified employees have strong negotiating power and they do not need a mediator to communicate with the manager.

It should be noted that the extremely fast development of SMEs in the emerging market economies in central and eastern Europe did not allow the social and economic actors to focus on building an institutional framework in the sector. Economic and social policy-makers were more interested in modernisation based on foreign direct investment (as was the case in Hungary) or on struggles over property ownership (as was the case in Bulgaria) and the development of the SME sector received peripheral attention. Goss has proposed a typology of managerial control, based upon a combination of two dimensions: the 'extent of employers' economic dependence upon employees' and the 'ability of employees to resist the exercise of the owners' prerogative' (Goss 1991). In the Hungarian case studies size was significant in shaping patterns of control, but was only one factor. In a number of cases employment relations were more formalised and codified, the growth of these organisations led to the increasing complexity of relationships between owners and managers, and employees, which required the use of new, standardised management tools to organise work and facilitate social consent (the changes arising from increased formalisation are discussed in Moore et al., in this issue). The case studies also draw attention to the growing importance of the outsourcing of noncore activities. In a small Hungarian clothing company with six employees, four employees worked in the company factory and the other two employees were employed as home workers. In the new economy - for example ICT - there appears to be a move towards more formal management models. The case study of a Hungarian interactive media company shows that during a period of growth the owners hired an organisational consultant. In cooperation with an international audit firm the company tried to create a more efficient organisational model, first implementing separate cost centres, and 
later introducing project-based work organisation. These cases suggest that there is a need to understand the management model in order to interpret employment relations and the question of representation. Yet in this case study employees criticised managerial decisions and one of the employees expressed an interest in more intensive participation in work-related decision-making:

Compared with my previous workplace it is a very bad thing that here we don't know where we are going. We give a lot of information to the management, but they inform us sometimes just at the last minute. Often in a given situation we don't know what to do to help achieve the company's long-term aims.

There is widespread belief that trade unions have difficulties in creating both representative institutions (e.g. collective bargaining) and employee participation structures (e.g. works councils) in SMEs. The opinion of a Hungarian trade union leader interviewed in the clothing industry sector summarises well the difficulties of implementing collective interest representation structures in the workplace in the post-socialist economies of the CEECs:

When big clothes factories closed down many people registered for unemployment benefit, but at the same time they started working in the black economy. It is hard to make these people understand what disadvantages they can suffer without being registered employees because until they have other alternatives they will not leave their black sector job. Frightening them with the ghost of being without a pension and health insurance is fairly useless until they are forced somehow to deal with this question. Many of those who are employed in the black economy are retired or have this as a part-time or a second job. This system works reasonably well as long as employers pay correctly, but alongside this there are many unstable elements. The badly defined job contracts and unregistered salaries press employers to exclude any third party from the relationship between themselves and the employees. This often leads to the high vulnerability of workers.

In some sectors there was low awareness of trade unions. The employees interviewed in the Bulgarian hotel did not know whether a trade union for those working in tourism existed. The same was true for employees working for a clothing company. This evidence suggests that there is a deficit in communication between trade unions and employees in small companies.

The Hungarian company case studies also indicate low awareness of unions or a perception that there was no need for them. Yet the absence of official institutions of labour relations does not mean a lack of social consent between the actors involved in the labour process. In other words, we have to stress the informality of employment relations and the rather paternalistic pattern of management in the firms surveyed. The case studies indicated that the intention of owners and managers of small firms to individualise employment relationships also appeared to reflect the wishes of employees. This latter phenomenon can be attributed to a preference for informality, but also to employees' lack of trust towards their trade unions. A number of employees, interviewed in both Bulgarian and Hungarian SMEs, shared a negative opinion of trade 
unions. According to a respondent working in a Bulgarian ICT company, the trade unions 'are visible only on paper but not in practice'. All of the respondents in a Bulgarian retail enterprise had heard about trade unions, but none of them declared an interest in their activities. A worker in a textile company affirmed, 'they pretend to have activities'. Another employee working for a hotel stated:

I don't rely on such organisations; in my opinion they just dangle their legs. They wouldn't stand for the rights of people like us. To me, this is pure bureaucracy.

The belief of those employees is that for the moment unions cannot do anything for them and this reflects a wider legacy. In many cases, trade unions lost their legitimacy because of their support for the social and economic reforms and their failure to address the ensuing problem of dismissals from the large enterprises during the 1990s.

\section{Collective bargaining}

In Bulgaria collective agreements exist for certain sectors where cases studies were located (hotels and catering, commerce and clothing). However these agreements were not reflected in the case study organisations. There was only one example of collective bargaining and this was a subcontracting company, which had been part of a former large state-owned enterprise, acquired by a Belgian multinational. The trade union organisation had been established in 2003 and its founders were about 70 workers almost all of them members of the trade union organisation of CITUB in the former company. The trade union section of the subcontracting company is a part of the union branch of the larger company of which it was a part. It had recently signed an agreement with the executive director for the collection of membership subscriptions (on the basis of a monthly deduction from salary) and was in the process of negotiating a collective agreement. This case study reflects the findings of the wider SMALL project, which showed that unionisation in SMEs may be inherited following the fragmentation of larger companies (see Moore $e t$ al., in this issue) and underlines the importance of preserving a trade union presence in externalised activities of large enterprises. None of the Hungarian case studies were covered by collective bargaining.

\section{Conclusions and policy recommendations}

In the cases of Bulgaria and Hungary, as in many CEE countries, SMEs are not covered by collective labour agreements and representative structures rarely exist. This represents a challenge for both social partners (trade unions and employers' organisations). Yet, the case study evidence of the SMALL project raises the question whether the SME sector is a priority for trade unions in CEECs. In Bulgaria and Hungary trade union representatives interviewed for the project complained that access to workers in SMEs was difficult; at the same time workers reported that in many cases they had not heard about trade union attempts to gain access to them.

However the problem of access and formal representation in the companies not only reflects trade union strategies, but also depends on the extent to which both employers and workers can be 'convinced' of the utility of social dialogue and the development of 
a culture of dialogue in general. Small businesses in CEECs are relatively new and their characteristics have a specific impact on employment relations. The possibility of collective mobilisation was undermined by individual strategies of survival, characteristic of the post-socialist economies, namely informal practices and secondary employment. Trade unions have responded to the problem of avoidance of regulation by SME employers (e.g. payment of minimum wages, lack of labour contracts) at national level, for example through the compulsory registration of labour contracts in Bulgaria and the introduction of minimal thresholds for representation.

However, there has been little activity at workplace level. In any case, the absence of formal channels of representation in the SMEs hides the existence of a number of compromises between employers and employees over matters such as wages, working time or health and safety conditions. Trade union action should be based on a clear understanding of these social realities. In addition, we have to stress the absence of a meaningful regional dimension in the labour relations systems in the former state-socialist economies. It may be necessary to rethink the existing sectoral approach to social dialogue and to combine this with a regional perspective. In this regard the CEECs could draw upon effective regionally based labour relations systems as exist in Italy.

A more 'reflective capacity' highlighting the differences and parallels between SMEs and the public sector and multinational companies could provide a better articulation of the representation of employees and better adaptation of appropriate organisational strategies. In the post-communist reality individual strategies for survival have undermined collective action; the history of unions' support for liberalisation after the fall of communism and their failure to address the associated attacks on workers' job security and living conditions have meant that unions have lost their legitimacy. They are now struggling to recruit and represent these same people now working in SMEs.

The case studies show that, on the one hand, SME owners often require information and support on employment issues and, on the other, workers need more information about their rights in the workplace. Workers have little knowledge of their rights to representation, particularly those in micro firms. This is especially relevant for health and safety and in relation to the legislative requirement for the establishment of representative committees. In this respect, the trade unions could be more active.

\section{References}

Agency for Small and Medium Enterprises (ASME) (2004) Small and Medium Enterprises in Bulgaria 2002-2003, Sofia.

http://www.sme.government.bg/en/AnnualReportSME2004EN.pdf

Aro, P. and P. Repo (1997) Trade Union Experiences in Collective Bargaining in Central Europe, Budapest: ILO.

Beleva, I. (2001) Politikata po zaetostta $i$ bezrabotitzata v Balgaria v prehodnia period. Analiz, otzenki, perspektivi, Sofia: Akademitchno izdatelstvo Marin Drinov. 
Chavance, B. (1995) 'Hierarchical Forms and Co-ordination Problems in Socialist Systems', Institutional and Corporate Change, 4 (1).

Dimitrova, D. and K. Petkov (2005) 'Comparative Overview: Changing Profiles, Action and Outcomes for Organized Labour in CEE', in D. Dimitrova and J. Vilrokx (eds.) Trade Union Strategies in Central and Eastern Europe. Toward Decent Work, Budapest: ILO.

Ebbinghaus, B. and J. Visser (2000) Trade Unions in Western Europe since 1945, London: Macmillan.

European Commission (2004) Industrial Relations in Europe 2004, Luxembourg: Office for Official Publications of the European Communities.

European Foundation for the Improvement of Living and Working Conditions (2001) 'Employment Relations in micro and small enterprises - literature review. Country Profile: Bulgaria', (available only in electronic format, part of the literature review Employment relations in micro and small firms), Dublin.

European Foundation for the Improvement of Living and Working Conditions (2003) Working conditions in the acceding and candidate countries, Dublin.

Eurostat (2003) SMEs in Europe - Candidate countries, Detailed Tables, Luxembourg: Office of the Official Publications of the European Communities.

Goss, D. (1991) Small Business and Society, London: Routledge.

Gradev, G. (2001) 'Bulgarian Trade Unions in Transition: Taming the Hedgehog', in S. Crowley and D. Ost (eds.) Workers after Workers' States: Labor and Politics in Postcommunist Eastern Europe, Boston, 121-140.

Hámor, Sz. (2002) Külön utakon jár a képzés és a gazdaság (Cégek nem támogatják a házon belüli tanulást, inkább 'kész' szakembereket keresnek) [Division between Training and the Economy. Instead of Training, Firms Looking for 'ready-made personnel], Népszabadság, 18.

ILO (1994) Balgarskoto predisvikatelstvo: Reformata na troudovia Pazar i sotzialnata politika [The Bulgarian challenge: Labour market and social policy reform], Budapest.

Kirov, V. (2005) 'Facing EU Accession: Bulgarian Trade Unions at the Crossroads', in D. Dimitrova and J. Vilrokx (eds.) Trade Union Strategies in Central and Eastern Europe. Toward Decent Work, Budapest: ILO, 111-151.

KNSB (2000) Tcherna kniga za naroucheniata na trudovite i sindikalni prava $v$ Balgaria, Sofia.

Kornai, J. (1992) The Socialist System: The Political Economy of Communism, Princeton: Princeton University Press, 400.

Központi Statisztikai Hivatal (Hungarian Central Statistical Office) (2006) Structural Business Statistical Data, Budapest: Központi Statisztikai Hivatal.

Makó, Cs. and P. Novoszáth (1995) 'Employment Relations in Multinational Companies: the Hungarian Case', in E. Dittrich, G. Schmidt and R. Whitley (eds.) Industrial Transformation in Europe: Process and Context, London: Sage Publications, 255-277.

Makó, Cs. and Á. Simonyi (1997) 'Inheritance, Imitation and Genuine Solutions (Institution Building in Hungarian-Labour Relations)', Europe-Asia Studies, 49 (2), March, 221-244. 
Neumann, L. (2002) EIRO Comparative Study on Collective Bargaining Coverage and Extension Procedures - The Case of Hungary, Budapest: Institute of Labour, Ministry of Employment Policy and Labour.

OECD (2004) Employment Outlook, Paris: OECD, chapter 3 ('Wage-setting outcomes and institutions').

Paoli, P. and A. Parent-Thirion (2003) Working conditions in the acceding and candidate countries, Dublin: European Foundation for the Improvement of Living and Working Conditions.

Román, Z. (2002) Small and Medium-sized Enterprises in the Hungarian Economy (State of Affairs and International Comparison), Budapest: Central Statistical Office.

Schienstock, G. (2004) 'From path dependency to path creation: A new challenge to the systems of innovation approach', in G. Schienstock (ed.) Embracing the Knowledge Economy (The Dynamic Transformation of the Finnish Innovation System), London: Edward Elgar.

Stoeva, S. (2005) Informal socio-economical processes in the context of the Bulgarian transformation, Dissertation, Sofia.

\section{Appendix 1: Distribution by size of manufacturing firms: planned economies versus capitalist ones (1970)}

\begin{tabular}{|c|c|c|}
\hline & Planned economies $^{1}$ & Capitalist economies $^{2}$ \\
\hline \multicolumn{3}{|l|}{ All manufacturing firms } \\
\hline 1. Average number of employees per firm & 197 & 80 \\
\hline 2. Percentage of those employed by large firms ${ }^{3}$ & $66 \%$ & $32 \%$ \\
\hline \multicolumn{3}{|l|}{ Textile industry } \\
\hline 1. Average number of employees per firm & 355 & 81 \\
\hline 2. Percentage of those employed by large firms & $75 \%$ & $17 \%$ \\
\hline \multicolumn{3}{|l|}{ The ferrous metal industry } \\
\hline 1. Average number of employees per firm & 253 & 82 \\
\hline 2. Percentage of those employed by large firms & $61 \%$ & $28 \%$ \\
\hline \multicolumn{3}{|l|}{ The chemical industry } \\
\hline 1. Average number of employees per firm & 325 & 104 \\
\hline 2. Percentage of those employed by large firms & $79 \%$ & $35 \%$ \\
\hline \multicolumn{3}{|l|}{ The food-processing industry } \\
\hline 1. Average number of employees per firm & 103 & 65 \\
\hline 2. Percentage of those employed by large firms & $39 \%$ & $16 \%$ \\
\hline
\end{tabular}

Notes

1 The sample includes the former Czechoslovakia, East Germany, Hungary and Poland.

2 The sample includes Austria, Belgium, France, Italy, Japan and Sweden.

3 Defined as employing more than 500 people.

Source: J. Kornai (1992) The Socialist System: The Political Economy of Communism, Princeton: Princeton University Press, p. 400. 